86. Sharp, D., 1898. Account of the Phasmidke with Notes on the Eggs. Willey. Zoöl. Results, Cambridge, p. 75-94.

87. v. Siebold, T., 1843. Bemerkungen über eine den Bacillus rossii bewohnende, Schmarotzer-Larve. Germar's Zeit. f. Ent. IV, p. 389-394.

88. Sinéty, R. de, 1900. Sur la parthénogénèse des Phismes [Orthopt.] Bull. Soc. ent. Fr. No. 9, p. 195-7.

89. - 1900. La mue chez les Phasmes du genre Leptynia [Orthopt.] Ibid. No. 11, p. 228-9.

90. - 1901. Recherches sur la Biologie et l'Anatomie des Phasmes. La Cellule XIX, p. 118-278.

91. Smith, F., 1867. [Remarks on King's (47) paper.] Jour. Proc. Ent. Soc. London, p. 80.

92. Snow, G. C., 1874, Walking-Sticks or Specters becoming Injurious. N. Y. Weekly Tribune, 11 Nov. Sb. No. 23, p. 103. Yates Co., N. Y. Reprint in: Ann. Rept. U. S. Com. Agric. 1878. Wash. p. 242.

93. Stockard, C. R., 1908. Habits, Reactions, and Mating Instinets of the WalkingStick, Aplopus mayeri. Publ. No. 103. Carnegie Inst., Wash. p. 43-59.

94. - 1909. Inheritance in the Walking-Stick, Aplopus mayeri. Biol. Bull. XVI, p. 239-245.

95. Thurau, F., 1899. Ber. Ent. Zeit. LXIV, Sitz. Oet. p. (15).

96. Thomson, A., 1882. Notes on a Species of Stick Insect reared in the InsectHouse in the Society's Garden. Proc. Zoöl. Soc. London, p. 718-9.

97. 1890. Report of the Insect-House for 1889. (Orthoptera; Diapheromera femorata) Ibid. p. 96.

98. Townsend, C. H. T., 1909. Descriptions of Some New Tachinidae, Ann. Ent. Soc. Amer. II, p. 243-250.

99. Trouvelot, L., 1866. Proc. Bost. Soc. Nat. Hist. XI, p. 89.

100. Wallace, A. R., 1878. Tropical Nature and other Essiys. p. 91-3.

101. Walsh, B. D., 1864. On Phytophagic Varieties and Phytophagic Species. Proc. Ent. Soc. Phila. III, p. 409 and p. 427.

102. Walsh, B. D., and Riley, C. V., 1868. The Stick-bug. Amer. Ent. I, p. 58.

103. Westwood, J. O., 1839. An Introduction to the Modern Classification of Insects. p. $430-6$.

TWO RHOPALOSIPHUM SPECIES AND APHIS PULVERULENS, N. SP.

By C. P. Gillette.

Rhopalosiphum pastinace (L.) and R. caprea (Fab.)

Apparently these two species have been confused by aphidologists. As I have material that seems to me to straighten out the tangle, I venture to give it.

The description of pastinace by Linnæus is satisfied about equally well by the louse I am considering as this species, and by the louse described by Fabricius, and later by Kaltenbach ${ }^{1}$ as caprex. At, least, the species considered in this paper as pastinace answers the Linnean description and does not answer the excellent description of caprece as given by Kaltenbach. More recent descriptions scem mostly to have been of caprece and under, several different names.

Rhopalosiphum caprece Fab. Perhaps the fact that Koch ${ }^{2}$ de-

1 Monographie der Pflanzenlause, 1843, p. 109.

2 Die Pflanzenlause Aphiden, 1857, p. 41. 
scribed and figured this species as pastinace has had much to do to cause the confusion of later writers. Koch's caprece seems to be neither this species nor pastinace. Buckton ${ }^{3}$ recognized the prominent distinctive characters of the two species, as did Passerine. Mr. J. T. Monell 1 obtained his salicis from willow and described the winged form without noticing the small supra-caudal tubercle. In a recent letter Mr. Monell has told me that he now considers his salicis synonymous with caprece Kalt. Doctor Weed ${ }^{5}$ later found the sexuales of this species on willow in Ohio and described them as Siphocorince salicis Monell. Mr. J. J. Davis has called my attention to the fact that Doctor Oestlund ${ }^{6}$ seems to have described this louse as archangelice which seems to me to be the case. I have not come upon any description of pastinaca since Buckton's, already mentioned, except that of xylostei Schr., which is probably a synonym of this species. The striking character in capree, which in the material that I have studied is constant in all forms, larvæ, alate and apterous viviparæ, sexuales, and pupæ, is the supra-caudal tubercle or spine which, in the apterous form, is as long or longer than the cauda, but which is a tubercle only in the alate forms (See figures.).

All the specimens of these two forms that I have seen, separate readily into two very distinct species without intergrading, and without a mingling of the two forms in the same lot as follows:

Joints 4, 5, 6, and antennal spur sub-equal, the spur usually distinctly the longest, cornicles fully $\%$ as long as $3 d$ joint of the antenna, a small tubercle on the alate form and a large one on the apterous individuals always present......... caprex.

Joint 6 of the antenna distinctly shorter than 5 , the 4 th still shorter and its spur nearly as long as joints 4,5 and 6 combined, cornicles seldom much exceeding $1 / 2$ the $3 \mathrm{~d}$ joint of the antenna in length, and supra-caudal tubercle or spine entirely absent ............................................ pastinace.

Kaltenbach called attention to the interesting habits of caprece in that it lived upon two very different groups of plants, the willows (Salix species). and several species of the Umbelliferæ. Later writers have added to the number of food plants but, so far as I have learned, they have all been willows or members of the parsley family.

The food plants given for caprece by the writers mentioned, and by Fabricius and Schrank are as follows:

Fabricius.-Salix caprea.

Schrank.-Willow.

Kaltenbach.-Salix amygdalina, babylonica, capree, and alba, Heracleum siphondylium, Angelica sylvestris, Aegopodium podograria, Choerophyllum temulum, Pastinacea sativa and Conium maculatum.

-Monograph of British Aphids, II, pp. 25, 27.

Bull. 5, U. S. Geol. Survey, 1879, p. 26.

Trans. Amer. Ent. Soc., 20, 1893, p. 297.

Aphididæ of Minn., 1887, p. 70. 
Koch.-Salix caprea.

Buckton.-Salix species.

Monell.-Salix lucida, nigra and babylonica.

Oestlund.-Angelica atropurpurea.

Weed.-Salix species.

From Mr. Bragg's collections made at Fort Collins, Col., I extract the following records: From parsley, Petroselinum hortense, August 25, 1907, October 5, 1907, November 1 to 25, 1910, and from willow, June 22, 1908. Mr. Bragg also took this species at Amherst, Mass., July 26, 1909, on Pastinaca sativa, and at Webster, Mass., July 26, on the same plant and on caraway, Carum carui.

Prof. Ellsworth Bethel of Denver, Col., sent me a fine lot of specimens which he took at Tolland, Col., at an altitude of 8,000 feet on Ligusticum porteri, October 19, 1908.

I have also received specimens from Prof. Edith M. Patch taken at Orono, Me., on caraway, July 29, 1910, and Mr. J. J. Davis wrote me from Chicago that he had taken the same louse in great numbers from Zizia aurea in Illinois.

So all the way through this species scems to hold to species of Salix for the winter host plant and to species of Umbelliferce for its mid-summer hosts as Kaltenbach pointed out when he wrote his description.

Rhopalosiphum pastinace (L.). Linnæus described this species from the common parsnip, Pastinaca sativa. The only subsequent description $I$ have seen of this species under this name is the one by Buckton in his Monograph, volume II, p. 25. It seems to me very probable that xylostei Schr. is a synonym of this species. Shrank's description would not indicate a different species; Kaltenbach's description of it fits pastinaca which he seems not to have known, and the description by Buckton hardly indicates that $x y l o s t e i$ is a good species. Schrank took this species from honeysuckle (Lonicera sp.); Buckton records his specimens from Lonicera xylostei and periclyneum; Kaltenbach's were from Lonicera periclyneum and Conium maculatum, and Koch records his from Lonicera xylostei. A slide from Mr. Monell labeled xylostei is marked "Lonicera pastinaca St. Louis, November 4" and I have just recently received specimens of what seems to be the same louse from Miss Mary Murtfeldt, Kirkwood, Mo., which she reported to be injuriously abundant upon honeysuckle nearly every year.

These references to xylostei records are given to show how perfectly the food plants fit in with those of what I have been calling pastinace, and which seems to have for its hosts several species of the Umbelli- 
fere during the summer months and the honeysuckles (Lonicera sp.) during fall, winter and spring.

Our specimens of pastinace have been taken by Mr. Bragg as follows: From Heracleum lanatum October 27 and 28, 1908, and November 1, 1908; in all cases alate viviparous females and a few winged males were taken but no oviparous females. From honeysuckles (Lonicera sp.) specimens were taken June 28, 1910, July 2, 1907, and September 28, 1910, all viviparous females; specimens taken October 9, 1910, October 11, 1910, November 7, November 10 and November 12,1910 , all had males and oviparous females.

The conclusions then are that these species of Rhopalosiphum have several species of the Umbelliferæ as summer host plants, that caprece goes to the willows for the fall, winter and spring, that pastinacee goes to the honcysuckles for the winter, that xylostei is probably a synonym of pastinace though I have no European material of this species to study, that Koch's pastinacere, Monell's salicis, and Oestlunds archangelice are all caprea.

Descriptions of Rhopalosiphum caprece. Plate 9, Figures 10-16.

Specimens from garden parsley, Petroselinum hortense, at Fort Collins, Colo., November 1, 1910.

Alate Viriparous Females.-Color of prothorax and entire abdomen green with slight pulverulence beneath. Head, antenne, mesothorax above and below, metathorax, tarsi, and distal ends of tibix black; legs otherwise yellowish green as are the cornicles and cauda; anal plate dusky, cornicles and cauda in some examples a little dusky. The cornicles are .30 to $.35 \mathrm{~mm}$. in length, slender at base and enlarging at the middle to twice the basal diameter and somewhat constricted again near the tip, which ends in a moderate flange; length of cauda, $.10 \mathrm{~mm}$.; above the cauda is a prominent tubercle from $1 / 3$ to $1 / 2$ the length of the cauda (see Fig. 11). Length of body 1.50 to $2 \mathrm{~mm}$; length of antenna 1 to $1.10 \mathrm{~mm}$; length of wing $2.60 \mathrm{~mm}$. Joints of antenna about as follows: III, .32-.37; IV, .13-.15; V, .12-.13; VI, .12-.13; spur, $.15-.17 \mathrm{~mm}$; joint III tuberculate with numerous sensoria.

Apterous l'viparous Female.-General color pale greenish to very pale yellowish with no dark parts but the eyes and tarsi. The striking peculiarity of this form is the tubercle upon the 8th segment which is as long as the cauda and blunt at the apex (see Fig. 12). Length of body 1.70 to $2 \mathrm{~mm}$.; cornicle $.40 \mathrm{~mm}$. long, the club being less abrupt than in the alate form. Antenna .80 mm. long; joints III, .20; IV, 10; $\mathrm{V}, .10$; VI, .10; spur, .13 $\mathrm{mm}$. There are distinct antennal tubercles and the body is remarkably smooth and free from hairs and on the dorsum the surface is minutely punctate.

The larva and pupa also show the tubercle well developed.

Alat' Ifale.-I have sgen but one male. It was taken from parsley November 1 , 1910, and differs from the alate viviparous female by being smaller, and by having a larger number of sensoria on joint 3 , about 7 on joint 4 , about 7 on joint 5 , and 4 on the sides of joint 6 . 
Aphis pulverulens, n. sp. Plate 9, Figures 1 to 9.

Specimens taken from Symphoricarpos occidentalis at Fort Collins, May 31, 1909; L. C. Bragg, collector.

Apterous Viviparous Female.-The body is covered with a white silvery secretion, giving it the appearance of a species of Pemphigus. When the secretion is removed, the body is of a sordid greenish brown color. The greater portion of the antennæ, the tarsi, distal ends of tibix, distal portion of beak and eyes are black, or blackish. The eyes are really a very dark red; the head and prothorax are a little dusky, as are the basal joints of the antennæ; the head and prothorax are very narrow; the antennæe are on somewhat prominent tubercles, which, however, have no length on the lateral margins next to the compound eyes; joint 6 of antenna tapering gradually into spur; cornicles short and weak and somewhat curved and light in color, very smooth and with little or no flange, diameter slightly greater near the base than near the distal end; cauda broadly rounded, and not more than half as long as it is wide on the basal margin; beak barely attaining third coxa; body very smooth and free from hairs.

Body varying little from $3 \mathrm{~mm}$. long by $1.07 \mathrm{~mm}$. wide. Length of cornicles $.21 \mathrm{~mm}$.; hind tibia $1.63 \mathrm{~mm}$; joints of antennæ: III, .90; IV, .49; V, .37; VI, .14; spur, $.57 \mathrm{~mm}$.

The larvæ are pale carncous and may be tinged with green.

It seems likely that these apterous females are stem-mothers.

Alate Viviparous Females. Reared from the same lot as the apterous form described above.

The entire body and legs are covered with a cottony secretion as in the apterous form. General color of body, legs and antenna the same as in the apterous. Lobes of the thorax above black, head and prothorax black or blackish, cornicles as in the apterous form except that they are dusky brown in color. Antenna with numerous hairs, and tuberculate sensoria; cauda small, rounded at apex, broader than long; cornicles weak and without flange; stigma of wing long, narrow and parallel sided, sccond fork of cubitus a little nearer the apex of the wing than to the first fork.

Length of body $3 \mathrm{~mm}$., width $1.34 \mathrm{~mm}$; antennæ $2.78 \mathrm{~mm}$.; joints of antennæ about as follows: III, .90; IV, .57; V, .43; VI, .13; spur, .59 mm.; cornicle, .20 mm.; wing, $4 \mathrm{~mm}$.

Male: Aptcrous, from stems at ground and on upper roots of Symphoricarpos occidentalis, taken at Fort Collins, October 15, 1910.

General color carneous, or yellowish brown; head, entire antennx, cornicles, tarsi, and distal ends of tibiæe and femora black or blackish; eyes dark red.

Length $1.90 \mathrm{~mm}$; antenna $1.84 \mathrm{~mm}$; joints of antenna: III, .60; IV, .36; V, .26; VI, .10; spur, .40 mm.

Antenna with a moderate number of short hairs; joint 6 tapers gradually into the spur; sensoria abundant on joint 3 and a few on joint 4 .

Oviparous Female: Apterous and a little darker than the viviparous female, also smaller and more elongate. Cornicles concolorous with the body; entire body more or less heavily powdered above and below; length of body $3 \mathrm{~mm}$.; cornicles weak, cylindrical, $.24 \mathrm{~mm}$. long, without flange; length of antenna $2.20 \mathrm{~mm}$.; joints about as follows: III, .70; IV, .35; V, .31; VI, .14; spur, .44 mm. Tarsi, distal ends of tibir and most of distal portion of the antenna black or blackish; hind tibiæe with numerous circular sensoria (or scent glands) on upper third of hind tibiæ. 


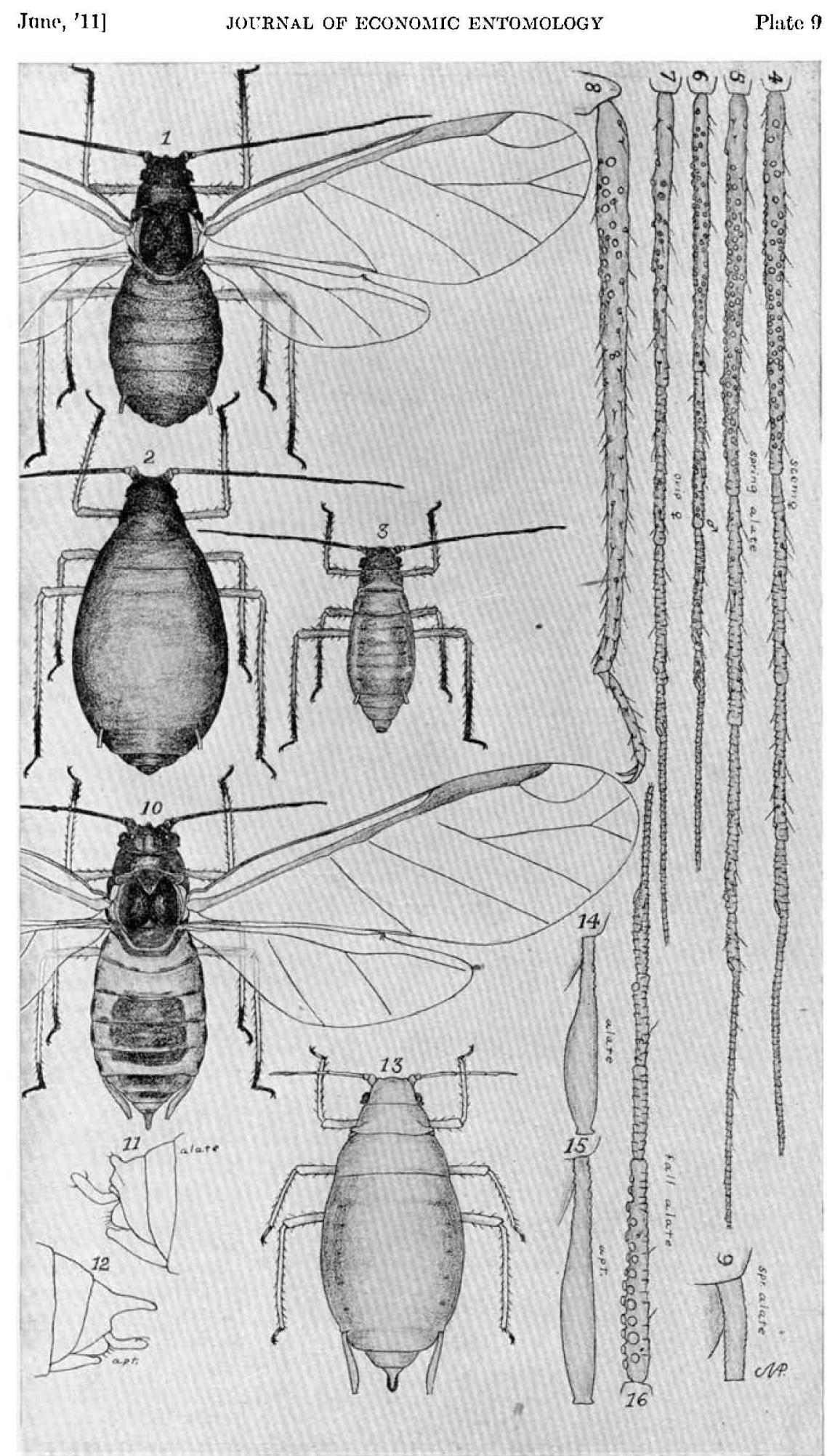

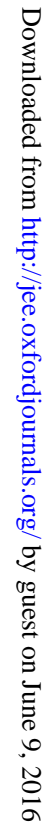

Aphid Struetures 
Eggs pale yellowish, covered somewhat with the waxy secretion but only accidentally; deposited on the lower stems just beneath the surface of the ground.

We have been taking this louse for the past three seasons about Fort Collins and always on Symphoricarpos at or below the surface of the ground throughout the year. It seems to be a bark feeder exclusively. While this louse may not properly belong in the genus $A$ phis, it fits here as well as in any genus known to me.

Plate 9, Figs. 1 to 9, Aphis pulverulens; Figs. 10 to 16 Rhopalosiphum caprex. 1, Alate; 2 , apterous viviparous females; 3 , male; 4 , antenna of Fig. $2 ; 5$, antenna of Fig. 1; 6, antenna of male; 7 , antenna of oviparous female; 8 , hind tibia of oviparous female; 9 , cornicle of alate female; 10 , alate viviparous female; 11 , end of abdomen showing tubercle of the preceding; 12, the large tubercle or spine of the apterous female; 13 , apterous female; 14 and 15 , cornicles of alate and apterous. females; 16 , antenna of alate female.

Figs. 1, 2 and 3 are enlarged 14 diameters; 4 to 9 enlarged 60 diameters; 10 and 13,20 diameters; 11 and 12,40 diameters; 14,15 and 16, 80 diameters. Original, Miss M. A. Palmer, Delineator.

\section{LIST OF THE APHIDIDAE OF ILLINOIS, WITH NOTES ON SOME OF THE SPECIES.}

(Concluded from p. 496, Vol. 3.)

By JoHn J. Davis, Office of the Slate Entomologist, Lrbana, Illinois.

${ }^{t}$ Phorodon scrophularice Thos.: 8th Rep. State Ent. Ill. (1880), p. 72. I have never seen this species, and it has only been recorded once since the original description, W. T. Clarke having reported collecting it in California on Scrophularia sp. ${ }^{1}$ First reported by Thomas.

*Phorodon galeopsidis Kalt.: What I consider this species and have described below was found quite common on Polygonum pennsylvanicum at Oak Park and Urbana from July to October. It doubtless occurs at other seasons on the same plant, but it has never been looked for other than in the months mentioned. It has not heretofore been recorded from America, although I surmise that the species referred to as Siphonophora polygoni by Thomas and Oestlund are this species. It colonizes on the under surface of the leaves, principally along the larger leaf veins. The oviparous female was not taken.

Wingel viniparous female.-Head dusky. (Pl. 10, fig. 3), thoracic plate dark olive, abdomen ycllowish to yellowish green with a dark dusky green rectangular spot on the dorsum, which sometimes is only present on the two segments anterior to the cornicles, and a row of very faint dusky spots on each side of the abdomen.

${ }^{1}$ A list of California Aphidida. Can. Ent. Vol. XXXV (1903), p. 252. 